\title{
HUBUNGAN PERAN KADER KESEHATAN JIWA DENGAN KEKAMBUHAN SKIZOFRENIA DI WILAYAH KERJA PUSKESMAS II DENPASAR TIMUR
}

\section{RELATIONSHIP OF THE ROLE OF MENTAL HEALTH CADRES WITH RECURRENCE OF SCHIZOPHRENIA}

\author{
Anak Agung Ketut Parwati1, Ns. Ni Ketut Ayu Mirayanti, S.Kep., M.Kep 2,. \\ Ns. Ni Ketut Citrawati, S.Kep., M.Kep 3 \\ 1Mahasiswa Program Studi S1 Ilmu Keperawatan STIKes Wira Medika Bali \\ 2Dosen Program Studi S1Ilmu Keperawatan STIKes Wira Medika Bali \\ 3Dosen Program Studi S1Ilmu Keperawatan STIKes Wira Medika Bali
}

\begin{abstract}
ABSTRAK
Gangguan jiwa merupakan salah satu masalah kesehatan masyarakat di Indonesia. Prevalensi gangguan jiwa berat, seperti skizofrenia di Indonesia mencapai sekitar 400.000 orang atau sebanyak 1,7 per 1.000 penduduk. Seseorang yang pernah mengalami gangguan skizofrenia akan kembali kambuh karena kondisi yang tidak terkontrol dan tidak meminum obat secara rutin. Pemberdayaan masyarakat seperti kader kesehatan jiwa bermanfaat untuk mengidentifikasi dan mengatasi masalah serta mempertahankan kesehatan jiwa masyarakat.

Penelitian ini bertujuan untuk mengetahui hubungan peran kader kesehatan jiwa dengan kekambuhan skizofrenia. Jenis penelitian ini termasuk penelitian observasional dengan pendekatan cross sectional. Penelitian dilakukan di wilayah kerja Puskesmas II Denpasar Timur, teknik pengambilan sampel menggunakan consecutive sampling dengan sampel sebanyak 52 responden.

Hasil penelitian didapatkan, kekambuhan skizofrenia sebanyak 30 orang $(57,7 \%)$ tidak kambuh dan sebanyak 22 orang $(42,3 \%)$ kambuh, untuk peran kader kesehatan jiwa kategori kurang sebanyak 31 orang $(59,6 \%)$ dan kategori baik sebanyak 21 orang $(40,4 \%)$. Hasil uji chi-square didapatkan angka p value sebesar $0,947$ ( $p>0,05)$, menunjukkan tidak ada hubungan peran kader kesehatan jiwa dengan kekambuhan skizofrenia di wilayah kerja Puskesmas II Denpasar Timur.

Berdasarkan hasil penelitian ini disarankan untuk meningkatkan pemberdayaan kader kesehatan jiwa untuk membantu masyarakat mencapai kesehatan jiwa yang optimal.
\end{abstract}

Kata kunci : peran kader, kekambuhan skizofrenia

\section{ABSTRACK}

Mental disorder is one of the public health problems in Indonesia. The prevalence of severe psychiatric disorders, such as schizophrenia in Indonesia reaches about 400.000 people or as many as 1.7 per 1.000 inhabitants. A person who has experienced schizophrenic disorder will recur because of uncontrolled conditions and not taking medication regularly. Community empowerment such as mental health cadres is useful to identify and solve problems and maintain the mental health of the community. 
The study aims to determine the relation of the role of mental health cadres with recurrence of schizophrenia. This type of research includes observational research with cross sectional approach. This research was conducted in the working area of Puskesmas II Denpasar Timur, sampling technique using consecutive sampling with the samples of 52 respondents.

The result of the research showed that recurrence of schizophrenia as many as 30 people $(57,7 \%)$ did not relapse and as many as 22 people 42,3\%) relapse, for the role of mental health cadre of less category as many 31 people $(59,6 \%)$ and category both as many as 21 people (40,4\%). chi-square test results obtained $p$ value of 0,947 ( $P>0.05)$, showed no correlation role of mental health cadres with recurrence of schizophrenia in work area Puskesmas II Denpasar Timur.

Based on the results of this study suggested to improve empowerment of mental health cadres to help people achieve optimal mental health.

Key words : role of cadres, recurrence of schizophrenia

\begin{tabular}{lll}
\hline Alamat Korespondensi & $:$ Jl. Pulau Kae No. 37 Denpasar \\
Email & $:$ Parwati_a a@yahoo.com \\
\hline
\end{tabular}

\section{PENDAHULUAN}

Gangguan jiwa merupakan salah satu masalah kesehatan masyarakat di Indonesia. Sebagian besar orang dengan gangguan jiwa mengalami penurunan kesehatan secara fisik yang akhirnya menurunkan produktivitas, baik dalam bekerja maupun dalam beraktifitas sehari-hari.

Hasil Riskesdas 2013 menunjukkan prevalensi gangguan jiwa berat, seperti skizofrenia di Indonesia mencapai sekitar 400.000 orang atau sebanyak 1,7 per 1.000 penduduk. Sedangkan di Provinsi Bali prevalensi skizofrenia sebesar 2,3 per mil, dan prevalensi skizofrenia di Kota Denpasar sebesar 1,0 per mil.

Skizofrenia merupakan bentuk gangguan dalam fungsi alam pikiran berupa disorganisasi (kekacauan) dalam isi pikiran yang ditandai antara lain oleh gejala gangguan pemahaman (delusi waham) gangguan persepsi berupa halusinasi atau ilusi serta dijumpai daya nilai realitas yang terganggu yang ditunjukan dengan perilaku-perilaku aneh. Dalam mencari penyebab skizofrenia unsur somato-psikososial harus diperhatikan. Terjadinya skizofrenia merupakan proses interaksi yang kompleks antara faktor-faktor seperti genetik, organo biologis, psikologis, serta sosio kultural. Telah terbukti ada hubungan erat antara timbulnya skizofrenia dengan kondisi sosial dan lingkungan di masyarakat sebagai suatu stesor psikososial (Efendi, 2009).

Seseorang yang pernah mengalami gangguan skizofrenia akan kembali kambuh karena kondisi yang tidak terkontrol dan tidak meminum obat secara rutin (Efendi, 2009). Pengenalan dan intervensi dini berupa obat dan psikososial sangat penting, karena semakin lama tidak diobati, kemungkinan kambuh semakin sering dan resistensi terhadap upaya terapi semakin kuat (Fadhli, 2010). Namun yang paling penting adalah bagaimana peran keluarga dan masyarakat pasca rehabilitasi, karena keluarga dan masyarakatlah yang dapat membantu mengurangi kekambuhan.

Keterlibatan masyarakat sangat diperlukan dalam upaya meningkatkan derajat kesehatan jiwa komunitas. Pemberdayaan masyarakat seperti kader kesehatan jiwa 
bermanfaat untuk mengidentifikasi dan mengatasi masalah serta mempertahankan kesehatan jiwa masyarakat. Kader kesehatan jiwa dapat membantu masyarakat mencapai kesehatan jiwa yang optimal melalui penggerakan masyarakat untuk memelihara dan meningkatkan kesehatan jiwa serta memantau kondisi kesehatan jiwa masyarakat di wilayahnya, sehingga tindakan pencegahan dapat dilakukan pada anggota masyarakat yang berisiko mengalami gangguan psikososial (Keliat, 2010).

Berdasarkan data Dinas Kesehatan Kota Denpasar jumlah penderita skizofrenia tercatat terbanyak di Puskesmas II Denpasar Timur yaitu sebanyak 105 orang, dan masih masih ada yang mengalami kekambuhan. Saat kunjungan langsung pada lima rumah penderita skizofrenia didapat informasi dari keluarga bahwa dalam satu bulan terakhir ada satu orang yang menyatakan anggota keluarganya yang skizofrenia mengalami gejala kekambuhan.

Dalam mengatasi masalah kekambuhan dan untuk meningkatkan kesadaran, kemauan dan kemampuan masyarakat dalam menghadapi masalah kesehatan jiwa sehingga akan terbentuk perilaku sehat sebagai individu, keluarga dan masyarakat diwilayah Kerja Puskesmas II Denpasar Timur, dilakukan pelayanan kesehatan jiwa dengan melaksanakan kunjungan rumah yang melibatkan perawat CMHN (Community Mental Health Nursing) dan pemberdayaan kader kesehatan jiwa. Kader kesehatan jiwa ini berperan dalam membantu pasien yang telah mandiri untuk mempertahankan kesehatannya, sedangkan pasien yang belum mandiri dirawat oleh perawat CMHN.

Dari uraian diatas, peneliti tertarik untuk menganalisis hubungan peran kader kesehatan jiwa dengan kekambuhan skizofrenia di wilayah kerja Puskesmas II Denpasar Timur.

\section{BAHAN DAN METODE}

Penelitian ini merupakan penelitian observasional dengan menggunakan rancangan cross sectional. Penelitian ini dilakukan di wilayah kerja Puskesmas II Denpasar Timur pada bulan April sampai dengan Juni 2018 dengan jumlah populasi sebanyak 105 keluarga orang dengan skizofrenia. Sampel dalam penelitian ini sebanyak 52 responden yang didapat menggunakan teknik non probability sampling dengan consecutive sampling yaitu teknik pemilihan sampel dengan cara menetapkan subjek yang memenuhi krieteria dalam kurun waktu tertentu sehingga jumlah sampel terpenuhi dan dapat mewakili populasi penelitian (Nursalam, 2013).

Variabel independen (bebas) dalam penelitian ini adalah Peran kader kesehatan jiwa variabel dependen terikat) adalah kekambuhan orang dengan skizofrenia). Instrumen yang digunakan untuk pemngumpulan data adalah kuesioner. Kuesioner telah diuji validitas dengan menggunakan uji Korelasi Product Moment Pearson, dan uji reliabilitas dengan uji Alpha Cronbach

Data yang sudah diolah dianalisa dengan analisis univariat untuk mendeskripsikan peran kader kesehatan jiwa dan kekambuhan skizofrenia, dan anlisa bivariat menggunakan uji chi-square untuk menganalisis hubungan peran kader kesehatan jiwa dengan kekambuhan skizofrenia. 


\section{HASIL}

Kondisi Lokasi Penelitian

Penelitian ini dilakukan di wilayah kerja Puskesmas II Denpasar Timur yang merupakan salah satu dari 2 Puskesmas yang ada di Kecamatan Denpasar Timur dengan luas wilayah Kerja $16 \mathrm{Km}^{2}$ yang terdiri dari 2 (dua) kelurahan dan 3 (tiga) desa yaitu: Kelurahan Penatih, Kelurahan Kesiman, Desa Penatih Dangin Puri, Desa Kesiman Petilan dan Desa Kesiman Kertalangu.

Program yang sudah dilakukan oleh Puskesmas II Denpasar Timur terkait dengan masalah kesehatan jiwa, salah satunya melalui upaya pemberdayakan masyarakat dengan membentuk kader kesehatan jiwa yang dapat membantu masyarakat mencapai kesehatan jiwa yang optimal melalui penggerakan masyarakat untuk memelihara dan meningkatkan kesehatan jiwa serta memantau kondisi kesehatan jiwa masyarakat sebanyak enam orang pada masing-masing desa/kelurahan

Karakteristik Subyek Penelitian

Tabel 1. Disrtibusi Frekuensi Responden Berdasarkan Umur, Tingkat Pendidikan, dan Hubungan Keluarga

\begin{tabular}{lll}
\hline Karakteristik Responden & $\begin{array}{l}\text { Frekuensi } \\
(\mathrm{n})\end{array}$ & $\begin{array}{l}\text { Persentase } \\
(\%)\end{array}$ \\
\hline Umur & & \\
$<25$ th & 2 & 3,8 \\
$>25$ th Total & 50 & 96,2 \\
Torndidikan & 52 & 100,0 \\
\hline Tingkat Prnding & & \\
Rendah & 8 & 15,4 \\
Menengah & 39 & 75,0 \\
Tinggi & 5 & 9,6 \\
$\quad$ Total & 52 & 100,0 \\
\hline Hubungan Keluarga & & \\
Orang tua & 16 & 30,8 \\
Suami/istri & 3 & 5,8 \\
Saudara & 29 & 55,8 \\
Anak Total & 4 & 7,7 \\
$\quad 52$ & 100,0 \\
\hline
\end{tabular}

Berdasarkan table 1 di atas, dapat dilihat bahwa karakteristik responden berdasarkan umur paling banyak dengan rentang usia diatas 25 tahun sebanyak 50 orang $(96,2 \%)$, sedangkan berdasarkan pendidikan sebagian besar responden memiliki tingkat pendidikan menengah yaitu sebanyak 39 orang (75\%), dan berdasarkan hubungan keluarga dengan penderita skizofrenia, paling banyak adalah saudara yaitu 29 orang $(55,8 \%)$ 
Variabel Penelitian

Tabel 2. Distribusi frekuensi kekambuhan orang dengan skizofrenia

\begin{tabular}{ccc}
\hline Kekambuhan & $\begin{array}{c}\text { Frekuensi } \\
\text { (n) }\end{array}$ & $\begin{array}{l}\text { Persentase } \\
(\%)\end{array}$ \\
\hline Kambuh & 22 & 42,3 \\
\hline Tidak Kambuh & 30 & 57,7 \\
\hline Total & 52 & 100 \\
\hline
\end{tabular}

Berdasarkan Tabel 2 di atas, dapat dilihat bahwa dari 52 orang dengan skizofrenia ada sebanyak 30 orang $(57,7 \%)$ tidak mengalami kekambuhan dalam sebulan terakhir.

Tabel 3 Distribusi frekuensi peran kader jiwa

\begin{tabular}{ccc}
\hline $\begin{array}{c}\text { Peran } \\
\text { Kader }\end{array}$ & $\begin{array}{c}\text { Frekuensi } \\
(\mathrm{n})\end{array}$ & $\begin{array}{l}\text { Persentase } \\
(\%)\end{array}$ \\
\hline Baik & 21 & 40,4 \\
\hline Kurang & 31 & 59,6 \\
\hline Total & 52 & 100 \\
\hline
\end{tabular}

Berdasarkan Tabel 3 di atas, menunjukan distribusi frekuensi peran kader kesehatan jiwa di wilayah kerja Puskesmas II Denpasar Timur termasuk dalam kategori kurang sebesar 59,6\%.

\section{Hasil Analisis Data}

Tabel 4 Hubungan peran kader kesehatan jiwa dengan kekambuhan skizofrenia

\begin{tabular}{|c|c|c|c|c|c|c|c|}
\hline \multirow{3}{*}{$\begin{array}{l}\text { Peran } \\
\text { Kader }\end{array}$} & \multicolumn{4}{|c|}{ Kekambuhan } & \multirow{2}{*}{\multicolumn{2}{|c|}{ Total }} & \multirow{3}{*}{ P Value } \\
\hline & \multicolumn{2}{|c|}{ Kambuh } & \multicolumn{2}{|c|}{$\begin{array}{c}\text { Tidak } \\
\text { Kambuh }\end{array}$} & & & \\
\hline & $\mathbf{N}$ & $\%$ & $\mathbf{N}$ & $\%$ & $\mathbf{N}$ & $\%$ & \\
\hline Baik & 9 & 17,3 & 12 & 23,1 & 21 & 40,4 & 0,947 \\
\hline Kurang & 13 & 25,0 & 18 & 34,6 & 31 & 59,6 & \\
\hline Jumlah & 22 & 42,3 & 30 & $\mathbf{5 7 , 7}$ & 52 & 100 & \\
\hline
\end{tabular}

Berdasarkan Tabel 4 di atas, menunjukan kader kesehatan jiwa kategori berperan baik pada penderita skizofrenia yang mengalami kekambuhan sebanyak 9 orang $(17,3 \%)$ dan yang tidak kambuh sebanyak 12 orang $(23,1 \%)$ Sedangkan peran kader dengan kategori kurang berperan penderita skizofrenia yang mengalami kekambuhan sebanyak 13 orang (25\%) dan yang tidak kambuh sebanyak 18 orang $(34,6 \%)$. Hasil uji statistik diperoleh nilai p sebesar 0,947, sehingga dapat disimpulkan bahwa tidak ada hubungan yang bermakna antara peran kader kesehatan jiwa dengan kekambuhan skizofrenia di wilayah kerja Puskesmas II Denpasar Timur. 


\section{Karakteristik Subyek Penelitian \\ Umur}

Berdasarkan hasil penelitian diketahui bahwa sebagian besar responden berumur diatas 25 tahun sebanyak 50 orang $(96,2 \%)$, ini termasuk usia dewasa dimana pada usia dewasa seseorang telah mempunyai kematangan emosional dan kemampuan untuk berfikir. Hal ini dapat menyebabkan responden memiliki kepekaan dalam berinteraksi sehingga akan peduli pada permasalahan yang ada disekitar. Notoatmodjo (2003) menjelaskan bahwa semakin cukup umur seseorang maka akan lebih matang dalam berfikir dan bekerja. Dengan kategori umur dewasa, keluarga akan dapat menerima dan memahami bagaimana merawat dan memenuhi kebutuhan penderita skizofrenia.

\section{Pendidikan}

Berdasarkan tingkat pendidikan responden sebagian besar memiliki tingkat pendidikan menengah yaitu sebanyak 39 orang $(75 \%)$. Pada tingkat pendidikan menengah ini responden sudah cukup mampu untuk memahami realitas yang terjadi sehingga dapat merawat penderita skizofrenia dengan baik. Ali (2009) menjelaskan bahwa semakin tinggi pendidikan seseorang, maka ia akan memiliki kemampuan yang semakin tinggi, dengan mengikuti pendidikan seseorang akan mampu memahami realitas yang tengah terjadi dan akan berkontribusi sesuai dengan apa yang bisa dilakukannya.

\section{Hubungan dengan penderita skozofrenia}

Berdasarkan hubungan keluarga respoden dengan penderita skizofrenia, paling banyak adalah saudara yaitu 29 orang (55,8\%). Menurut Efendi (2009) keluarga merupakan sekumpulan orang dengan ikatan perkawinan, kelahiran, dan adopsi yang bertujuan untuk menciptakan, mempertahankan budaya, dan meningkatkan perkembangan fisik, mental, emosional, serta sosial dari tiap anggotanya, sehingga keluarga sangat berperan penting dalam tahap-tahap perawatan kesehatan, mulai dari tahapan peningkatan kesehatan, pencegahan, pengobatan sampai dengan rehabilitasi.

\section{Kekambuhan Orang Dengan Skizofrenia}

Hasil penelitian ditemukan kekambuhan orang dengan skizofrenia dalam satu bulan terakhir adalah tidak kambuh sebanyak 30 orang $(57,7 \%)$ dan kambuh sebanyak 22 orang $(42,3 \%)$.

Seseorang yang pernah mengalami gangguan skizofrenia akan kembali kambuh karena kondisi yang tidak terkontrol dan tidak meminum obat secara rutin (Efendi, 2009). Pengenalan dan intervensi dini berupa obat dan psikososial sangat penting, karena semakin lama tidak diobati, kemungkinan kambuh semakin sering dan resistensi terhadap upaya terapi semakin kuat (Fadhli, 2010).

Dari penelitian yang dilakukan terkait kekambuhan skizoferenia oleh Ronald (2016), mengenai kepatuhan konsumsi obat, pengetahuan dan dukungan keluarga terhadap frekuensi kekambuhan penderita skizofrenia di Desa Sriharjo Imogiri Bantul, didapatkan bahwa kepatuhan konsumsi obat, dukungan dan pengetahuan keluarga berpengaruh terhadap frekuensi kekambuhan penderita Skizofrenia. 
Berdasarkan penjelasan diatas peneliti berasumsi bahwa penderita skizofrenia di wilayah kerja Puskesmas II Denpasar Timur sebagian besar kondisinya sudah terkontrol dan patuh minum obat secara rutin. Hal ini juga terkait dengan peran keluarga dan masyarakat terutama kader kesehatan jiwa yang secara rutin memantau kegiatan dan kondisi kesehatan orang dengan skizofrenia di wilayahnya.

\section{Peran Kader Kesehatan Jiwa}

Hasil penelitian ini menunjukan peran kader kesehatan jiwa lebih banyak kategori kurang dengan jumlah sebanyak 31 orang $(59,6 \%)$, sedangkan kategori baik sebanyak 21 orang $(40,4 \%)$.

Peran dan fungsi kader kesehatan jiwa berdasarkan program-program pada desa siaga sehat jiwa mencakup kader menemukan dan melaporkan kasus-kasus psikososial maupun gangguan jiwa yang terjadi dimasyarakat; menggerakan individu, kelompok, dan masyarakat untuk mengikuti program kesehatan jiwa dimasyarakat; kader melakukan kunjungan rumah yang mana didalamnya kader memantau kemampuan pasien dalam mengatasi masalah, dan memantau keterlibatan keluarga dalam merawat pasien; selain itu kader juga merujuk kasuskasus psikososial dan gangguan jiwa dimasyarakat pada perawat CMHN (Community Mental Health Nursing) atau tempat pelayanan kesehatan, kader juga membuat catatan atau laporan perkembangan kemampuan pasien gangguan jiwa dalam pendampingan baik melalui kunjungan rumah, penggerakan individu, pelaporan kasus yang ada diwilayahnya (Keliat, 2010).

Sesuai penelitian Iswanti (2018) yang mengeksplorasi peran kader kesehatan jiwa dalam melakukan penanganan gangguan jiwa di RW 06 Kelurahan Gemah Kota Semarang, didapatkan kesimpulan meliputi : peran kader kesehatan jiwa dalam penyuluhan dengan melakukan pendekatan pada keluarga yang mengidap gangguan jiwa, dan melaksanakan pemantauan perkembangan individu dengan gangguan jiwa. Melakukan kegiatan TAK dan rehabilitasi sesuai dengan prosedur pelaksanaan. Memberikan informasi untuk menggerakkan keluarga untuk melakukan rujukan pada pasien dengan gangguan gangguan jiwa. Melakukan pendokumentasian sesuai lembar observasi yang sudah tersedia

Dalam penelitian ini sebagian besar responden menilai peran kader kesehatan jiwa masih kurang, peneliti berasumsi kurangnya peran kader kesehatan jiwa karena keterbatasan waktu dan pengetahuan dari kader dalam melakukan kunjungan rumah untuk memantau perkembangan kondisi kesehatan jiwa penderita skizofrenia. Namun secara umum dapat disimpulkan bahwa kader kesehatan jiwa sangat berperan dalam membantu masyarakat mencapai kesehatan jiwa yang optimal melalui penggerakan masyarakat untuk memelihara dan meningkatkan kesehatan jiwa serta memantau kondisi kesehatan jiwa masyarakat di wilayahnya.

\section{Hubungan Peran Kader Kesehatan Jiwa Dengan Kekambuhan Skizofrenia}

Hasil analisis menunjukan bahwa tidak ada hubungan yang bermakna antara peran kader kesehatan jiwa dengan kekambuhan skizofrenia di wilayah kerja Puskesmas II Denpasar Timur, didukung dengan hasil analisis chi-square diperoleh $p$ value sebesar 0,947 ( $p>0,05)$. Hal ini diartikan bahwa peran kader kesehatan jiwa tidak berhubungan secara bermakna dengan kekambuhan skizofrenia.

Penelitian ini sejalan dengan penelitian yang dilakukan oleh Edi (2015), mengenai hubungan antara peran kader jiwa dengan motivasi keluarga dalam 
merawat pasien gangguan jiwa di wilayah kerja Puskesmas Kotagede I, dimana hasil penelitiannya juga menunjukan tidak ada hubungan yang signifikan antara peran kader dengan motivasi keluarga dalam merawat pasien gangguan jiwa di wilayah kerja Puskesmas Kotagede I dengan nilai $p$ value sebesar 0,596 pada taraf kepercayaan $95 \%$.

Dilihat dari hasil penelitian ini dan dari teori yang mendukung, peneliti menarik kesimpulan peran kader kesehatan jiwa tidak berhubungan secara langsung dengan kekambuhan skizofrenia, namun kader kesehatan jiwa berperan dalam meningkatkan, memeliharan dan mempertahankan kesehatan jiwa masyarakat dengan pendampingan melalui kunjungan rumah untuk memantau kepatuhan minum obat, keteraturan kontrol ke pelayanan kesehatan, dan kemampuan penderita dalam mengatasi masalah, serta memantau keterlibatan keluarga dalam merawat penderita skizofrenia, selain itu kader kesehatan jiwa juga melakukan rujukan serta pencatatan atau laporan perkembangan kesehatan.

\section{Simpulan}

\section{SIMPULAN DAN SARAN}

Kekambuhan orang dengan skizofrenia sebanyak 30 orang $(57,7 \%)$ tidak mengalami kekambuhan dan ada sebanyak 22 orang (42,3\%) yang mengalami kekambuhan di wilayah kerja Puskesmas II Denpasar Timur.

Peran kader kesehatan jiwa di wilayah kerja Puskesmas II Denpasar Timur. termasuk dalam kategori kurang sebesar 59,6\%.

Tidak ada hubungan yang bermakna antara peran kader kesehatan jiwa dengan kekambuhan skizofrenia di wilayah Kerja Puskesmas II Denpasar Timur.

\section{Saran}

Bagi Puskesmas disarankan untuk dapat meningkatkan pemberdayaan kader kesehatan jiwa yang telah mengikuti sosialisasi program CMHN (Community Mental Health Nursing) dan pelatihan kader kesehatan jiwa. untuk membantu masyarakat mencapai kesehatan jiwa yang optimal.

Kader kesehatan jiwa agar meningkatkan peran dalam melakukan kunjungan rumah, penggerakan individu, menemukan dan melaporkan kasus, merujuk kasus, dan membuat catatan atau laporan perkembangan orang dengan skizofrenia di wilayah kerja Puskesmas II Denpasar Ti ur.

Disarankan untuk keluarga agar pempertahankan konsistensi serta dapat meningkatkan kemampuan dalam merawat dan lebih aktif memantau status kesehatan anggota keluarga yang mengalami skizofrenia

\section{DAFTAR PUSTAKA}

Ali, M. 2009. Pendidikan Pembangunan Nasional Menuju Bangsa Indonesia yang Mandiri dan Berdaya Saing Tinggi. Jakarta: Imtima

Arikunto, 2014. Prosedur Penelitian Suatu Pendekatan Praktik. Jakarta: Rineka Cipta

Craig \& Davies, 2009. ABC Kesehataan Mental, (Alih bahasa Alifa Dimanti). Jakarta : EGC

Direja, A.H.S., 2011. Buku Ajar Asuhan Keperawatan Jiwa. Yogyakarta: Nuka Medika 
Edi, E.K, Suwarsi, Syafitri E.N., 2015. Hubunan antara peran kader jiwa dengan motivasi keluarga dalam merawat pasien gangguan jiwa di wilayahkerja Puskesmas Kotagede I. Available: medika,respati.ac.id $>$ article (28 Maret 2018)

Efendi \& Makhfudi, 2009. Keperawatan Kesehatan Komunitas Teori dan Praktik dalam Keperawatan. Jakarata: Salemba Medika

Fadhli, A., 2010. Buku Pintar Kesehatan Anak. Yogyakarta: Pustaka Anggrek.

Kaunang I, Esrom K, Vanri K., 2015. Hubungan Kepatuhan Minum Obat Dengan Prevalensi Kekambuhan Pada Pasien Skizofrenia yang Berobat Jalan di Ruang Poliklinik Jiwa Rumah Sakit Prof Dr. V. L. Ratumbuysang Manado. ejournal keperawatan (e-Kp) Volume 2. Nomor 2. Mei 2015. Available: www.ejurnalhealth.com (1 Maret 2018)

Keliat, B.A., Panjaitan, R.U, Riasmini, M., 2010. Manajemen Keperwatan Jiwa Desa Komunitas Desa Siaga, Jakarta: EGC

Keliat, B.A., Helena, N., Farida P., 2011. Manajeme Keperawatan psikososial \& Kader Kesehatan Jiwa CMHN (Intermediate Course). Jakarta: EGC

Kemenkes., 2013. Riset Kesehatan Dasar, (online), available: www.depkes.go.id (26 Pebruari 2018)

Kurnia, F.Y.P, Tyaswati, J.E, Abrori, C., 2015. Faktor-Faktor yang Mempengaruhi Terjadinya Kekambuhan Pada Pasien Skizofrenia di Poli Psikiatri RSD Dr. Soebandi Jember. e-Jurnal Kesehatan, Vol. 3 (no. 3), September 2015. ISSN 2355-178X. Available: http://jurnal.Unej.ac.id (20 Maret 2018)

Maramis, W.F., 2008. Catatan Ilmu Kedokteran Jiwa, Surabaya: Airlangga University Press

Notoatmodjo. 2003. Pendidikan dan perilaku kesehatan, Jakarta: PT. Rineka Cipta . 2012. Metodologi Penelitian Kesehatan, Jakarta: PT. Rineka Cipta

Nursalam, 2013. Metodologi Penelitian Ilmu Keperawatan, Edisi 3, Jakarta: Selemba Medika

Raharjo, A.B., 2014. Faktor-Faktor yang Mempengaruhi Kekambuhan Pada Pasien Skizofrenia di RSJD dr.Amino Gondohutomo Semarang. Jurnal Ilmu Keperawatan dan Kebidanan (JIKK). Available: ejurnal.stikestelogorejo. ac.id. (1 Maret 2018)

Ronald, 2016. Kepatuhan Konsumsi Obat, Pengetahuan dan Dukungan Keluarga Terhadap Frekuensi Kekambuhan Penderita Skizofrenia di Desa Sriharjo, Imogiri, Bantul. Jurnal Kesehatan Masyarakat - Vol. 09 No. 01/ Maret/ 2016. Available. Jurnal.stikes-wirausada.ac.id (1 Maret 2018)

Samsara, 2010. Skizofrenia dan diagnose Banding, Jakarta: Balai Penerbit FKUI

Sari, F.S, 2017. Dukungan Keluarga dengan Kekambuhan pada Pasien Skizofrenia di RSUD Dr. Achmad Mochtar Bukittinggi. Jurnal Pembangunan Nagari Volume 2 Nomor 1 Edisi Juni 2017: 1 - 18. Available: ejurnal.sumbarprov. go.id (24 Pebruari 2018)

Semiun Y, 2006. Kesehatan Mental 3. Yogyakarta: Kanisius

Simanjuntak, J., 2008. Konseling Gangguan Jiwa \& Okultisme, Jakarta: PT. Gramedia

Sugiyono, 2017. Metode Penelitian kuantitatif, kualitatif, dan R\&D. Bandung: Alfabeta 